\title{
Relationship between Individual Social Responsibilities and Personal Values of Teacher Candidates
}

\author{
Asuman Seda Saracaloğlu ${ }^{1} \&$ Ceren Saygı Gerçeker ${ }^{2}$ \\ ${ }^{1}$ Department of Educational Sciences, Adnan Menderes University, Aydın, Turkey \\ ${ }^{2}$ Department of Music, Adnan Menderes University, Aydın, Turkey \\ Correspondence: Ceren Saygı Gerçeker, Department of Music, Adnan Menderes University, Aydın, Turkey. \\ E-mail: cerensaygi2005@yahoo.com
}

\author{
Received: July 1, $2018 \quad$ Accepted: August 5, $2018 \quad$ Online Published: September 27, 2018 \\ doi:10.5539/ies.v11n10p64 URL: https://doi.org/10.5539/ies.v11n10p64
}

\begin{abstract}
The aim of this study is to reveal the relationship between individual social responsibilities and personal values of primary school and music teacher candidates on the basis of gender, school grade and department variables. Survey model among quantitative methods was used in the research. The research sample consist of $162(69.8 \%)$ primary school teacher candidates and $70(30.2 \%)$ music teacher candidates receiving education in Adnan Menderes University Faculty of Education. 146 (62.9\%) of the participants are female, and 86 (37.1\%) were male teacher candidates. Also 104 (44.8\%) freshman and 128 (55.2\%) senior students were joined into the research. Questionnaire on Individual Social Responsibility and Questionnaire on Personal values were used as data collection tools. SPSS 21.00 statistics software was used for data analysis. Due to the normal distribution of data, t-test and one-way analysis of variance were conducted, then Pearson correlation coefficients were calculated and regression analysis was performed. According to the obtained findings, personal values total scores of the participating teacher candidates did not significantly differ based on their gender and department, whereas they significantly differed in a school-grade based evaluation. The individual social responsibility total scores of the teacher candidates did not show a statistically significant difference on the basis of gender. Individual social responsibility levels were found to differ significantly based on school grade and department variables. Statistically significant positive and low level (between .18 and .39) correlations were found between the teacher candidates' social responsibilities and academic average and personal values subscales.
\end{abstract}

Keywords: individual social responsibility, personal values, primary school, teacher candidate, music teacher candidate

\section{Introduction}

Individuals feel the need of various things during their lifetimes. Such as biological-emotional-aesthetical and social needs. A system of beliefs affects people when they make decisions and take actions regarding these fields. Ulusoy and Dilmaç (2015, p. 16) defined values as "the beliefs that involve the personality attributes which make humans human, make them unique and govern their behaviors". This system of beliefs, referred to as "values", is defined in various ways in literature. Values are desired as non-situational targets that guide people's lives with varying significance levels. Values reflect desires, preferences and wishes; hence, they represent one's belief as to whether something is desirable or not (Güngör, 1993, p. 19). Halstead \& Taylor (2000) define the concept of value as a set of principles and bases that guide behavior in terms of being good or private. Rokeach, Schwartz, Allport, Feather and various other social scientists put emphasis on different aspects of this definition. In these definitions; they draw attention to values' being permanent, their hierarchical structure, and their role as a guide for individuals' and societies' lives.

Aydın (2003) provided a summary of how value is defined as: (a) they are the facts that involve beliefs and habits, (b) they help individuals realize and internalize their actions, (c) values generally consist of the things desired by individuals, (d) they can relate to several fields, and these fields of interest may involve a separate system of values (e) regardless of their source, they are social. According to Fichter (2006), values attach meaning to societies and they develop within the frame of a society's autonomy. General aspects of values were also stated as being attached much importance by people, and its relationship with preservation of common prosperity and fulfillment of needs (Cited by Dilmaç \& Bircan, 2015, p. 4). Values play an important role in understanding individuals, since 
evaluation of values is a fundamental method in understanding humans and societies. In individual and social sense beliefs, attitudes and behaviors have priority in understanding the value systems of different cultures (Roy, 2003, pp. 1-2).

According to Rokeach, a value "is an enduring belief that a specific mode of conduct or end-state of existence is personally or socially preferable to an opposite or converse mode of conduct or end-state of existence" (1973, p. 5). Values govern the behaviors of individuals while using the standards for evaluating selfness (Rokeach, 1973; Rohan \& Zanna, 1998; cited by. Demirutku \& Sümer, 2010, p. 18). The characteristics of behaviors and therefore the values that guide life are as follows: affecting personal behaviors, facilitating decision-making in different choices, controlling behaviors, full of emotion, shaping behaviors, strengthening thought and understanding (Limthanakom, Lauffer, Mujtaba, \& Murphy Jr., 2008). Beyond the striking differences in the value priorities of groups there is a surprisingly widespread consensus regarding the hierarchical ranking of the values. Average value hierarchies of representative and near representative samples from 13 nations exhibit a similar pattern that replicates with school teachers in 56 nations and college students in 54 nations. Benevolence, self-direction, and universalism values are consistently most important; power, tradition, and stimulation values are least important; and security, conformity, achievement, and hedonism are in between. Value hierarchies of $83 \%$ of samples correlate at least. 80 with this pan-cultural hierarchy. To explain the pan-cultural hierarchy, the researchers discuss its adaptive functions in meeting the requirements of successful societal functioning (Schwartz \& Bardi 2001).

Rokeach (1973, p. 28) made an extensive classification of values, which has been adopted by several other researchers. In this classification, values are categorized in two categories as terminal values (goals); and instrumental values which constitute the requirements to achieve terminal values. Terminal values involve family safety, afterlife welfare, a peaceful world, the feeling of success, wisdom, equity, real friendship, a world of beauty, an exciting life, inner peace, self-esteem, happiness, mature love, freedom, a comfortable life, social approval, national security and pleasure. Instrumental values can be listed as being liberal, clean, merciful, responsible, brave, independent, intellectual, imaginative, passionate and obedient, being able to self-control, being gentle, rational, capable, cheerful, affectionate and benevolent.

Gürkan, Çamlıer, and Saracaloğlu (2000) determined the primary basic values of Physical Education (P.E.) teacher candidates in three different universities as family safety, freedom, self-respect, a peaceful world, intelligence and wisdom, by using Rokeach's Values Survey. It was found that the least important values were determined respectively as pleasure, religious maturity (afterlife welfare/happiness), national security, an eventful live and mature love and the most important instrumental values were listed as being honest, independent, responsible, rational and intellectual.

Providing a definition of "being responsible", which is listed among the instrumental values of Rokeach, may provide more insight into the subject. Yavuzer (1998, p. 107) defined responsibility as "fulfillment of the duties by children as of their early childhood period in accordance with their age, gender and developmental stage" (Cited by Yurtal \& Yontar, 2006, p. 412). Responsibility is also defined as children's capability to voluntarily embark on a work, successfully fulfill the undertaken task, and undertake the outcomes and effects of their behaviors on themselves and others (Unutkan, 2005). Likewise, Pehlivan (2003) also defined responsibility as an individual's tendency to undertake the outcomes of his/her verbal or physical actions or behaviors that come under his/her authority. Responsibilities can also be categorized as social and individual responsibilities.

Individuals can modify the values that they possess through the interaction process that they experience, as the school life constitutes the main part of value-acquisition process (Oğuz, 2012). School life has critical importance in establishment of values, either explicitly or implicitly. In this context, life sciences and social studies curricula have particular importance in providing students with fundamental values. As also reported by Gömleksiz and Cüro (2011), social studies curriculum helps students in developing positive attitudes towards patriotism, cultural values, respect, environment and nature, responsibility and science.

Responsibility is an innate characteristic of human beings and its development is closely related to their communication with their social environment. As a human characteristic, responsibility is shaped within social structure (Güngör, 1993). Accordingly, two factors are considered to be effective in emergence of responsibility as a merit: socialization and education. Human beings are inherently social creatures and this attribute of humans is developed within society and through education. Humans' field of perception for responsibility expands towards their environment, society, nation and all other humans on the basis of their level of socialization and education. Individuals display different senses of responsibility against different factors. An individual has responsibilities towards his/her family, friends, environment, government, other nations, nature and other living creatures (Töremen, 2011). In this context, teacher candidates should be assisted in achieving a consciousness level so as to 
undertake their own duties and act accordingly.

Y1ldırım (2016) carried out a work with 11th grade students ( $\mathrm{N}=427)$ on the relationship between secondary school students' individual responsibility levels and mental health, and reported no significant difference between the adolescents' school type and their individual responsibility levels. Also parents' educational levels, and their marital and employment status were not effective on adolescents' responsibility levels. Furthermore, female students were found to be more responsible than male students, also the responsibility levels were found to decrease with increasing time consumption at internet and social media, and the first borns were found to have higher responsibility levels whereas single children displayed lower.

The factors related to individual responsibility involve individual efforts to strengthen one's self-respect, adoption of a respectful communication with others, being responsible for one's preferences and undertaking their consequences, person's governing-directing his/her own life, physical and emotional well-being, and feeling and thinking in a responsible manner (Özen, 2009, p. 24). Individual responsibility also involves determination of straight goals in life, and complete admission and acceptance of all responsibilities and duties required to achieve these goals. Individuals with high responsibility levels are capable of achieving the undertaken duties even under extreme conditions and enduring any consequence of their actions (Nelson \& Low, 2004).

Another concept used to define the responsibility of individuals towards others is "social responsibility". Social responsibility covers all corporate actions for providing social benefits, and responsibilities towards the target groups that need to be fulfilled (Akınc1-Vural \& Coşkun, 2011, p. 62). In the research carried out by Kocabaş (2014), the students of all faculties and higher schools in a university $(\mathrm{N}=623)$ were asked to define social responsibility, and they depicted this concept as mutualization, social sensitivity, sensitivity towards natural environment, social duties, social activities for benefit of society, individual consciousness, sensitivity towards social environment, conscientious responsibility, charities-nongovernmental organizations, corporate duties towards public, and supporting educational activities, in the descending order of frequency. In conclusion, one fourth of the university students were found to perceive social responsibility as mutualization.

Secchi (2007) proposed that, the concept of social responsibility is related to the term "corporate", thus, it should not be directly associated with individuals by scholars (Secchi, 2009, p. 566). At this very point, addressing the concept of corporate social responsibility will help us better understand the subject. Corporate social responsibility involves the non-profit activities of organizations related to ever-changing global values on the basis of volunteering.

Mohr, Webb, and Haris (2001, p. 47) defined corporate social responsibility as "the commitment of corporations to minimize or eliminate their harmful effects on the society, and maximize their long-term beneficial activities" (Cited by Aktan \& Börü, 2007, p. 7). The concept of individual social responsibility is closely associated with corporate social responsibility. Individual social responsibilities are in fact already available among the traditions of Turkish society. These traditions commonly emphasize a sense of unity through religious sayings such as "one who sleeps full when his/her neighbor is hungry, is not one of us" or through collective-voluntary daily actions.

Eraslan (2011) listed the various aspects of individual social responsibility as follows: (a) It is based upon the notion of volunteering. It involves individual's sensitivity towards his/her immediate/far environment and his/her efforts towards solution of others' problems (b) individual's tendency to have and raise awareness towards what happens around him/her c) It is an affective process (d) It is not limited to the diagnosis of the problem, but also involves a course of project-cooperation and acquisition of results (e) It involves not only general fields (education, environment, health, etc.) but also specific fields (animal rights, street children, etc.). Individual social responsibility is closely related to individuals' responsibilities towards social groups in which they are not involved. Active cooperation of individuals to deliver solutions to the problems of their society is the essence of social responsibility. Improving the society and its constituents is among the most important goals of social responsibility (Hatch \& Stephan, 2015, pp. 64-65).

Briefly, individual responsibility is related to being sensitive towards society and people in need. The abovementioned aspects constitute the basis for the definition of modern humans. Providing individuals with a value-based and social awareness is essential in educational process as well. As stated by Y1lmaz (2011), having an in-depth understanding of the society, the power distribution within, as well as the social problems and their sources holds great importance for teachers throughout the course of improving social responsibilities, since the profession of teaching is directly related with conveyance, modification and transformation of the society's culture. In this respect, social responsibilities of teacher candidates also need to be elaborated.

Various national and international studies are available on the variables related with social responsibility. Aktepe and Yel (2009) used Rokeach Values Survey in their research. 71 teacher candidates, reached via convenience 
sampling method, participated in their research. As a result of the research, no significant difference was detected between social and personal values.

The Educational Survey Support Program of the Ministry of National Education Department of Research and Development of Education was used by Taşdan (2010) who used screening and quantitative method. 599 state and 593 private primary school teachers participated in the research. As a result of the research, a medium level, positive significant relationship was detected between the participating teachers' scores for perception of individual and corporate values. The congruence level was found to be higher among teachers working in private schools as compared to state schools; and no significant difference was found between the personal values of overall sample and the corporate values of the school in terms of socio-economic level, educational level and graduation. The congruence level of male teachers working in private schools was higher than female teachers. On the other hand, congruence levels of primary school teachers working in state schools were found to be higher than those of branch teachers working in the same schools.

In a study, which elaborated the perception of responsibility among teachers in seven different subscales (responsibilities towards family, personal [academic], personal [health], interpersonal relationships, towards environment, religious and towards public [citizenship]), (Sezer, Çoban, and Akşit, 2017); interpersonal relationships was reported to be the most prominent scale, while the lowest scores were received from the responsibility towards environment and personal [health] subscales. The requirements of self-sacrifice and responsibility, fulfillment of students' needs, and a tight communication with students and their parents, led to high inter-personal relationship scores and in turn low health responsibility scores.

Karadağ (2017) carried out a work on determination of social responsibilities of educational institutions, related applications and the obstacles related to their implementation, in light of teacher perceptions $(\mathrm{N}=40)$. The main results obtained from the research are: Teachers perception of social responsibilities gathers within the frame of legal responsibilities, volunteering responsibilities and ethical responsibilities; their active social responsibility participations involve student-oriented activities, parent-oriented activities and environment-oriented activities. The social responsibilities of educational institutions include legal responsibilities, volunteering responsibilities, ethical responsibilities and economical responsibilities. Educational institutions' level of fulfillment of their social responsibilities was found to be low and the obstacle before social responsibilities are those arising from stakeholders, and corporate obstacles. Also, the social responsibility applications performed by educational institutions were found to have social, corporate, student-oriented and parent-oriented contributions.

The opinions of lecturers $(\mathrm{N}=30)$ working in a faculty of education were asked in a study on responsibility-oriented education for teacher candidates (Töremen, 2011). The opinions of lecturers were gathered under four main themes, namely, attitudes towards school, voluntary social activities, tolerance-oriented education and sharing. Reportedly, teacher candidates needed to internalize the values related to the senses of social sensitivity and responsibility to acquire these values. The participants put particular emphasis on the requirement for teaching the underlying logic, and what these values meant for the individual and society, for internalization of these values.

In the literature survey, no study was encountered on the collective investigation of personal values and individual social responsibility. In this aspect, this study is expected to make an important contribution to the field of educational sciences. In the present research, answers to the following questions were sought.

1) Do personal values of primary school and music teachers significantly differ based on their;

a) Gender

b) School grade

c) Department

2) Do individual social responsibilities of primary school and music teachers significantly differ based on their;

a) Gender

b) School grade

c) Department

3) Is there a significant relationship between primary school and music teacher candidates' personal values and individual social responsibilities?

\section{Method}

Screening model, one of the quantitative research methods, was used in the research. According to Karasar (2004, p. 77), screening models are the research approaches which aim to provide an in-situ depiction of past or present 
situations. In case of the present research, the case which is the subject of the study is based on the principle that: "individuals or objects should be defined as they are within the framework of their respective conditions". In other words, screening works are related to collection of data as to the prescribed characteristics of a specific group (Büyüköztürk, Çakmak, Akgün, Karadeniz, \& Demirel, 2014).

\subsection{Study Group}

Research sample consist of $162(69.8 \%)$ primary school teacher candidates and $70(30.2 \%)$ music teacher candidates. $146(62.9 \%)$ of the participants are female and $86(37,1 \%)$ are male candidates. Also $104(44.8 \%)$ freshman and $128(55.2 \%)$ senior students were joined into the research.

\subsection{Data Collection Tools}

\subsubsection{Individual Social Responsibility Scale (ISRS)}

This scale was developed by Eraslan in 2011, and is a single factor scale consisting of 28 items. Its Cronbach's Alpha Reliability Coefficient is .86 'dır. Split-half reliability is .74 for the first half, and .78 for the second half. The positive items in the Likert type scale are "absolutely agree" (5), "agree" (4), "indecisive" (3), "disagree" (2), "absolutely disagree" (1); and the negative items are "absolutely agree" (1), "agree" (2), "indecisive" (3), "disagree" (4), "absolutely disagree" (5). Accordingly, the highest possible score is 225 , and the lowest possible score is 45 . Cronbach's alpha reliability coefficient was calculated as.83. Split-half reliability is .72 for the first half, and.71 for the second half.

\subsubsection{Personal Values Inventory (PVI)}

Personal Values Inventory was developed by Roy in 2003. Its Turkish adaptation and reliability study was introduced by Asan, Ekşi, Doğan and Ekşi in 2008. Its original form consists of 55 items and its Turkish form consists of 47 items, as those under .30 were eliminated. The scale comprises of 5 factors namely discipline and responsibility, confidence and forgiveness, honesty and sharing, respect and rightness, sharing and respect. The Cronbach's Alpha reliability coefficient is .63 . The reliability coefficients of the subscales vary between .60 and .71. The scale is in likert 5 type as; 1) Does not define me at all, 2) Rarely defines me, 3) Sometimes defines me, 4. Generally defines me, and 5. Always defines me. In this study, the reliability coefficients were calculated as $.88, .71, .74, .63$ and .80 for discipline and responsibility, confidence and forgiving, honesty and sharing, respect and rightness, sharing and affection, respectively. The overall Cronbach's alpha reliability coefficient of the scale is .90 .

\subsubsection{Collection and Analysis of Data}

Research data were collected by the researchers. The permission of the related department and the consent of the related academician were received prior to data collection. The sample group was notified of the objective and importance of the research for proper collection of data. The explanations related to the scale were made and the questions of the students were replied. SPSS 21.00 statistics software package was used in data analysis. T-test and one-way analysis of variance were implemented since the research data exhibited a normal distribution. In addition, Pearson correlation coefficients were calculated to determine whether a relationship exists between the participants' individual social responsibility total scores and their personal values total scores. Finally, regression analysis was applied on the obtained data.

\section{Findings and Comments}

This section involves the findings and comments as to the sub-problems of the research.

\subsection{Personal Values}

The personal values of teacher candidates were examined and their total responses are given in Table 1.

Table1. Total responses of teacher candidates regarding their personal values

\begin{tabular}{lccccc}
\hline Personal values & $\mathrm{N}$ & $\mathrm{x}$ & $\mathrm{s}$ & $\mathrm{Min}$ & $\mathrm{Max}$ \\
\hline Discipline and responsibility & 232 & 4.0650 & .5186 & 2.13 & 5.00 \\
Confidence and forgiveness & 232 & 3.1683 & .5671 & 1.67 & 4.67 \\
Honesty and sharing & 232 & 3.9637 & .5261 & 2.00 & 5.00 \\
Respect and rightness & 232 & 3.4935 & .4944 & 2.17 & 5.00 \\
Sharing and respect & 232 & 4.2026 & .6699 & 1.50 & 5.00 \\
\hline
\end{tabular}


The personal value scores of the primary school and music teacher candidates are; sharing and respect $(\mathrm{x}=4.2026)$, discipline and responsibility $(\mathrm{x}=4.0650)$, honesty and sharing $(\mathrm{x}=3.9637)$, respect and rightness $(\mathrm{x}=3.4935)$, and confidence and forgiveness ( $\mathrm{x}=3.1683$ ), in the descending order. Accordingly, confidence and forgiveness value is "medium" level, sharing and respect value is "very high" level, and discipline and responsibility, honesty and sharing values are "high" level. In this context, the participating teacher candidates can be considered to have significantly high level of personal values.

\subsection{Gender}

T-test was performed as a means to reveal whether the personal values of the participating sample group significantly vary in a gender-based evaluation, and the results are shown in Table 2.

Table 2. Gender-based T-test results of teacher candidates' personal values

\begin{tabular}{cccccccc}
\hline & Groups & $\mathrm{N}$ & $\mathrm{x}$ & $\mathrm{s}$ & $\mathrm{sd}$ & $\mathrm{t}$ & $\mathrm{p}$ \\
\hline \multirow{2}{*}{ Discipline and responsibility } & Female & 146 & 4.0707 & .5396 & & & \\
& Male & 86 & 4.0580 & .4958 & 182.829 & .641 & \multirow{2}{*}{.526} \\
& Female & 146 & 3.1389 & .5996 & & & \\
Confidence and forgiveness & Male & 86 & 3.2041 & .5269 & 230 & -1.353 & .177 \\
& Female & 146 & 3.9788 & .5619 & & & \\
Honesty and sharing & Male & 86 & 3.9452 & .4823 & 183.197 & .607 & .545 \\
& Female & 146 & 3.5357 & .5353 & & & \\
Respect and Rightness & Male & 86 & 3.4420 & .4380 & 230 & -.568 & .571 \\
& Female & 146 & 4.2024 & .7286 & & & \\
Sharing and respect & Male & 86 & 4.2029 & .5961 & 187.353 & .582 & .561 \\
\hline
\end{tabular}

As shown in Table 2, gender-based personal value scores of the participating teacher candidates do not differ significantly in discipline and responsibility, confidence and forgiveness, honesty and sharing, respect and rightness, and sharing and respect subscales.

\subsection{School Grade}

The results of the t-test analysis performed to reveal whether the participating individuals' personal value scores significantly differ on the basis of school grade, are shown in Table 3.

Table 3. T-test results of teacher candidates' personal value scores based on school grade

\begin{tabular}{|c|c|c|c|c|c|c|c|}
\hline & Groups & $\mathrm{N}$ & $\mathrm{x}$ & $\mathrm{s}$ & sd & $\mathrm{t}$ & $\mathrm{p}$ \\
\hline \multirow{2}{*}{ Discipline and responsibility } & Freshmen & 104 & 3.9767 & .5034 & \multirow{2}{*}{230} & \multirow{2}{*}{-2.326} & \multirow{2}{*}{$.021 *$} \\
\hline & Seniors & 128 & 4.1696 & .5205 & & & \\
\hline \multirow{2}{*}{ Confidence and forgiveness } & Freshmen & 104 & 3.0582 & .5579 & \multirow{2}{*}{230} & \multirow{2}{*}{-2.666} & \multirow{2}{*}{$.009 * *$} \\
\hline & Seniors & 128 & 3.2988 & .5538 & & & \\
\hline \multirow{2}{*}{ Honesty and sharing } & Freshmen & 104 & 3.9505 & .5637 & \multirow{2}{*}{221.974} & \multirow{2}{*}{,- 337} & \multirow{2}{*}{.736} \\
\hline & Seniors & 128 & 3.9794 & .4813 & & & \\
\hline \multirow{2}{*}{ Respect and rightness } & Freshmen & 104 & 3.4257 & .5175 & \multirow{2}{*}{219.668} & \multirow{2}{*}{-1.861} & \multirow{2}{*}{.065} \\
\hline & Seniors & 128 & 3.5738 & .4563 & & & \\
\hline \multirow{2}{*}{ Sharing and respect } & Freshmen & 104 & 4.1416 & .7019 & \multirow{2}{*}{230} & \multirow{2}{*}{-1.229} & \multirow{2}{*}{.221} \\
\hline & Seniors & 128 & 4.2750 & .6272 & & & \\
\hline
\end{tabular}

As shown in Table 3, Discipline and Responsibility and Confidence and Forgiveness subscale scores differ depending on school grades, whereas no significant change is observed in the other subscales. The difference is in favor of 4th seniors.

\subsection{Departments}

The results of the t-test analysis performed to reveal whether the participating individuals' personal value scores significantly differ on the basis of departments are shown in Table 4. 
Table 4. Department-based t-test results of teacher candidates' personal values

\begin{tabular}{|c|c|c|c|c|c|c|c|}
\hline & Groups & $\mathrm{N}$ & $\mathrm{x}$ & $\mathrm{s}$ & sd & $\mathrm{t}$ & $\mathrm{p}$ \\
\hline \multirow{2}{*}{ Discipline and responsibility } & Primary School teach. cand. & 162 & 4.109 & .492 & \multirow{2}{*}{230} & \multirow{2}{*}{1.150} & \multirow{2}{*}{.252} \\
\hline & Music teach. cand. & 70 & 4.013 & .546 & & & \\
\hline \multirow{2}{*}{ Confidence and forgiveness } & Primary School teach. cand. & 162 & 3.164 & .608 & \multirow{2}{*}{230} & \multirow{2}{*}{-.086} & \multirow{2}{*}{.932} \\
\hline & Music teach. cand. & 70 & 3.172 & .519 & & & \\
\hline \multirow{2}{*}{ Honesty and sharing } & Primary School teach. cand. & 162 & 3.994 & .482 & \multirow{2}{*}{230} & \multirow{2}{*}{.780} & \multirow{2}{*}{.437} \\
\hline & Music teach. cand. & 70 & 3.928 & .573 & & & \\
\hline \multirow{2}{*}{ Respect and rightness } & Primary School teach. cand. & 162 & 3.467 & .478 & \multirow{2}{*}{129.250} & \multirow{2}{*}{-.697} & \multirow{2}{*}{.487} \\
\hline & Music teach. cand. & 70 & 3.523 & .513 & & & \\
\hline \multirow{2}{*}{ Sharing and respect } & Primary School teach. cand. & 162 & 4.228 & .657 & \multirow{2}{*}{230} & \multirow{2}{*}{.516} & \multirow{2}{*}{.607} \\
\hline & Music teach. cand. & 70 & 4.109 & .492 & & & \\
\hline
\end{tabular}

As shown in Table 4, the personal value scores of the participating teacher candidates do not differ significantly in a department-based evaluation.

\subsection{Individual Social Responsibility}

The individual social responsibility scores of the teacher candidates were analysed. The results are given in Table 5.

Table 5. Total responses of teacher candidates with respect to individual social responsibilities

\begin{tabular}{cccccc}
\hline & $\mathrm{N}$ & $\mathrm{x}$ & $\mathrm{s}$ & $\mathrm{Min}$ & $\mathrm{Max}$ \\
\hline Individual Social Responsibility & 232 & 3.7153 & .5183 & 2.21 & 5.00 \\
\hline
\end{tabular}

Individual social responsibility scores $(x=3.7153)$ of primary school and music teacher candidates were found to be "high" in general.

\subsubsection{Gender}

Individual social responsibility scores of the teacher candidates were evaluated on the basis of their gender and the results are shown in Table 6.

Table 6. Gender-based distribution of teacher candidates' individual social responsibility scores

\begin{tabular}{ccccccc}
\hline Groups & $\mathrm{N}$ & $\mathrm{X}$ & $\mathrm{S}$ & $\mathrm{sd}$ & $\mathrm{t}$ & $\mathrm{p}$ \\
\hline Female & 146 & 3.7797 & .5237 & 230 & 2.494 & $.013^{*}$ \\
Male & 86 & 3.6059 & .4929 & & & \\
\hline
\end{tabular}

${ }^{*} \mathrm{p}<.05$.

As shown in Table 6, individual social responsibility scores of the participating teacher candidates differ significantly in favor of female participants.

\subsubsection{School Grade}

Individual social responsibility scores of the teacher candidates were also evaluated on the basis of their school grade and the results are shown in Table 7.

Table 7. School-grade based distribution of teacher candidates' individual social responsibility scores

\begin{tabular}{ccccccc}
\hline Groups & $\mathrm{N}$ & $\mathrm{X}$ & $\mathrm{S}$ & $\mathrm{sd}$ & $\mathrm{t}$ & $\mathrm{p}$ \\
\hline Freshmen & 104 & 3.6370 & .4949 & \multirow{2}{*}{230} & 2.583 & $.01^{*}$ \\
Seniors & 128 & 3.8116 & .5324 & & & \\
\hline
\end{tabular}

$* \mathrm{p}<.01$. 
As shown in Table 7, the participating teacher candidates' individual social responsibility scores differ significantly in favor of 4 th senior students.

\subsubsection{Departments}

The responses of participating teacher candidates to the individual social responsibility survey were analysed with t-test and the results are shown in Table 8.

Table 8. Department-based distribution of teacher candidates' individual social responsibility scores

\begin{tabular}{ccccccc}
\hline Groups & $\mathrm{N}$ & $\mathrm{X}$ & $\mathrm{S}$ & $\mathrm{sd}$ & $\mathrm{t}$ & $\mathrm{p}$ \\
\hline Primary School Teacher & 162 & 3,6469 & .4295 & \multirow{2}{*}{230} & \multirow{2}{*}{2.060} & $.041^{*}$ \\
Music Teacher. & 70 & 3,7448 & .5508 & & & \\
\hline
\end{tabular}

$* \mathrm{p}<.05$.

As also indicated by Table 8 , individual social responsibility scores of classroom and music teacher candidates significantly differ in favor of music teacher candidates.

Pearson correlation coefficients were evaluated to determine whether a relationship exists between the teacher candidates' grade-point averages (GPA) and their individual social responsibility and personal value scores. The findings are shown in Table 9.

Table 9. The correlation between teacher candidates' individual social responsibilities and other variables

\begin{tabular}{|c|c|c|c|c|c|c|c|}
\hline & 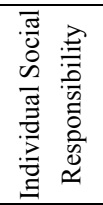 & 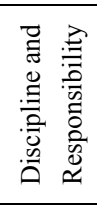 & 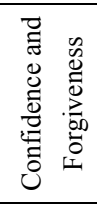 & 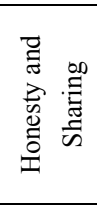 & 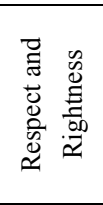 & 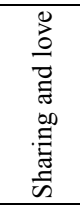 & త్ర \\
\hline Individual Social Responsibility & 1 & & & & & & \\
\hline Discipline responsibility & $.579 * *$ & 1 & & & & & \\
\hline Confidence forgiveness & -.029 & $.303 * *$ & 1 & & & & \\
\hline Honesty sharing & $.556^{* *}$ & $.821 * *$ & $.281 * *$ & 1 & & & \\
\hline Respect rightness & $.152 *$ & $.471 * *$ & $.601 * *$ & $.500 * *$ & 1 & & \\
\hline Sharing affection & $.577 * *$ & $.772 * *$ & $.166^{* *}$ & $.741 * *$ & $.338 * *$ & 1 & \\
\hline GPA & $.159 *$ & .039 & .090 & .035 & -.002 & -.033 & 1 \\
\hline
\end{tabular}

${ }^{*} \mathrm{p}<.05,{ }^{* *} \mathrm{p}<.01$.

Table 9 shows that, positive and "medium" level correlations exist between individual social responsibility and discipline-responsibility $(\mathrm{r}=.579, \mathrm{p}<.01)$, honesty and sharing $(\mathrm{r}=.556, \mathrm{p}<.01)$ and sharing and affection $(\mathrm{r}=.577$, $\mathrm{p}<.05$ ). Also, a positive and weak correlation was detected between individual social responsibility and GPA $(\mathrm{x}=159, \mathrm{p}<.01)$, and respect and rightness $(\mathrm{r}=.152, \mathrm{p}<.05)$. Also there are positive, medium and weak correlations between personal values and its subscales.

Regression analysis was performed to determine the variables that predict individual social responsibility and the results are given in Table 10. 
Table 10. Results of multiple regression analysis for performed to predict teacher candidates' individual social responsibility

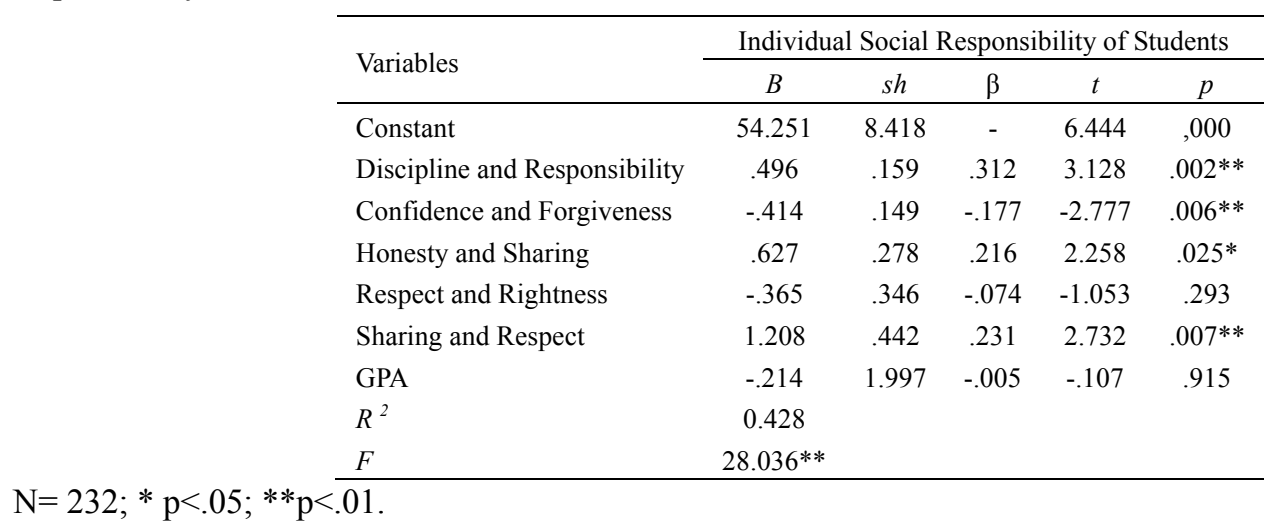

As a result of the multiple regression analysis performed to examine the participants' individual social responsibilities, $43 \%$ of the variance was found to be explained by discipline and responsibility, confidence and forgiveness, sharing and respect, and honesty and sharing scores $\left(R^{2}=.43\right)$. After the ANOVA analysis, applied to determine the significance level of regression analysis, four independent variables were found to have important descriptive effect $\left(F_{6-232}=28.036, p=.000\right)$. After the analysis of standardized regression coefficients $(\beta)$, the descriptive variables were ranked as discipline and responsibility score $(\mathrm{r}=.31)$, sharing and respect score $(\mathrm{r}=.23)$, honesty and sharing score $(r=.22)$ and confidence and forgiveness score $(r=18)$. Accordingly it can be concluded that, discipline and responsibility, confidence and forgiveness, sharing and respect, and honesty and sharing scores describe $43 \%$ of the variability in individual social responsibility.

\section{Results}

According to the obtained results, the personal values of teacher candidates do not significantly differ depending on their gender and department. On the contrary, a significant difference in the discipline and responsibility and confidence and forgiveness subscales in favor or 4th senior students. On the other hand, teacher candidates' individual social responsibility scores were found to differ significantly based on the gender, school grade and department variables. In this respect, significant results are obtained in favor of 4th seniors and music teaching students. Also, the individual value and individual social responsibility scores of the participants were found to be of "high" level in general.

\section{Discussion}

The personal value scores of the participating teacher candidates did not significantly vary on the basis of their gender in discipline and responsibility, confidence and forgiveness, honesty and sharing, respect and rightness, sharing and respect subscales. Likewise, the results of Roy's (2003) work did not indicate any significant difference among the personal values in a gender based evaluation. This indicated that, personal values are independent of gender and that the participants have personal values of similar levels.

Özdemir and Sezgin (2011) carried out a study on the order of importance among personal and corporate values, those expected from students, and their relationship, and they reported a significant gender-based difference between empathy, confidence, tolerance and risk values. Başol, Bilge, and Kuzgun (2012) elaborated the relationship between vocational high school students' personal values, physical status of the organization, life satisfaction levels of students and their demographic attributes, which are the effective parameters on students' career values. In the research, they used the terminal part of Rokeach's (1973) values survey. As a result, independent working among career values, and universality and being positive among personal values were found to significantly differ based on gender. In terms of universality, female students were reported to possess a more universal structure of values as compared to male students. This was associated with female students' more tolerant character with higher sensitivity towards social justice as compared to male students. On the other hand, male students received higher "being positive" scores. In this regard, male students were considered to place more emphasis on the values that pursue the welfare of their social circle and the general well-being of their society, as compared to female students.

Bacanlı (2002), Gürkan, Çamlıyer, and Saracaloğlu (2000) reported with regard to teacher candidates that, male students attached more importance to the issues of paying respect to traditions and being religious. A survey of 
Finnish, Swedish and Estonian university students by Verkasalo, Daun, and Niit (1994, as cited in Myyry \& Helkama, 2001) revealed that the primary value orientations of the students were universalism and benevolence and that females had higher scores than males. Saracaloğlu, Uça, Baydilek, and Coşkun (2013) applied Portrait Value Questionnaire and accordingly they reported that, teacher candidates' perceptions of values differed significantly depending on their gender. Female students' perceptions of values were found to be significantly higher than male students. In another study, all values except power, significant difference was on behalf of females (Saracaloğlu, Saygı-Gerçeker, \& Aladağ, 2018). Altunay and Yalçınkaya (2011) reported that, female teacher candidates attached more importance on all value scales as compared to male students.

In modern era, the roles attached to males and females have become increasingly similar. Now, women are increasingly engaged in professions which were once known as male jobs, or males undertake more jobs and duties which were once associated with females. Duties, responsibilities and social role expectations have become significantly similar. Thus, the significant difference in the gender factor of the research can be attributed to ever-changing and evolving social role expectations.

In the school grade variable, as the second variable of the research, Discipline and Responsibility and Confidence and Forgiveness subscales varied on the basis of school grade, whereas no significant difference was observed in the other subscales. Both values were in favor of senior students. Saracaloğlu, Saygi-Gerçeker, and Aladağ (2018) reported that, when the value scores of primary school and music teacher candidates were examined, all the values except for power were on behalf of freshmen. In another research (Gürkan, Çamlıyer, \& Saracaloğlu, 2000), terminal values did not differ depending on school grade, whereas only rational and clean among instrumental values showed significant difference.

Higher scores obtained by 4 th senior students in school grade variable are mainly attributable to the fact that, these students' have fulfilled several academic works and responsibilities for a period of four years, in addition to the sense of being more close to their professional lives. Throughout their university lives most of these students may have lived apart from their family and dealt with problems such as social life, accommodation, and earning extra income. Such processes may have forced them to become more disciplined and responsible individuals.

The personal value subscale scores of participating teacher candidates were found to not differ significantly on the basis of their department. In the research conducted by Saracaloğlu et al. (2013), it was observed that value perceptions of teacher candidates showed significant difference in self-direction (autonomy) and universalism sub dimensions according to department variable. The source of the difference in self-direction value was between the primary school teaching and science education, on behalf of science education; the source of difference in universalism value was between preschool education and primary school teaching, on behalf of preschool education, and between primary school teaching and science education, on behalf of science education. Another study which aims to examine the social values that teacher candidates possess and their critical thinking levels were carried out at two universities in Turkey on the students studying in the Departments of Science Teaching, Social Studies, Music Education, Primary School Teaching, and Guidance and Psychological Counseling (N= 994). Prospective teachers' values were traditional, religious, scientific, study-work, political and family values, respectively (Saracaloğlu, Evin-Gencel, \& Altın, 2016). It was detected that teacher candidates had high levels of value perceptions and the three most important values were universalism, security and self-direction. It was found that there was a statistically significant difference in primary school and music prospective teachers in all values except achievement, hedonism and stimulation according to their departments. Primary school teacher candidates have higher scores in all the basic values than music teacher candidates (Saracaloğlu, Saygi-Gerçeker, \& Aladağ, 2018). Myyry and Helkama (2001, p. 26) compared the values of the university students having education in different departments $(\mathrm{N}=138)$. In the research, power and achievement values of the students in faculty of economics, universalism value of social sciences students and security value of in technical fields were found high.

Personal values variable's showing no significant difference on the basis of departments can be ascribed to the fact that, one of the most affective aspects of the profession of teaching is the sense of responsibility. An educational process consists of the factors such as student, plan, goal and curriculum, etc. A teacher is the one who manages this process. A good sense of responsibility for timely fulfillment of teaching duties is a critical requirement for completion of this process with qualified learning, and achievement of the targeted learning outcomes. In this regard, teacher candidates' receiving similar responsibility scores despite working in different departments is an expected finding.

The gender based individual social responsibility scores of the participants have been found to differ significantly, in favor of female students. Tunca (2012) reported a significant difference in "being cooperative" subscale in favor of female students and reported no significant difference in other subscales and in total score of teachers' 
professional value levels. Also, female teachers received higher scores in all subscales and in total scores. Likewise, a research conducted with $11^{\text {th }}$ grade students showed that, female students displayed higher responsibility levels than male students (Yıldırım, 2016). Ercan (2009) stated that, teachers' opinions on the importance of social responsibility showed significant differences at all scales (being role model, contribution and support, respect and responsibility, social personality) in a gender based evaluation. Their opinion on implementation level of social responsibility differed significantly in Contribution and Support subscale.

In another research, no significant difference was reported between the social responsibility scale scores of the nurses (Erdoğan, 2016). Likewise, global social responsibility levels of social studies teacher candidates ( $N=463)$ studying in four different universities did not show statistically significant difference on the bases of gender, academic success, father's educational status, occupation of parents, parental income status, and having received the Community Service Practices (CSP) course (Başer, 2015). Kocabaş (2014) reported that, the general judgements of university students as to social responsibility did not significantly differ based on their gender. Cengil (2015) further proposed that $(\mathrm{N}=150)$ female and male university students did not show significant difference in terms of sense of responsibility and related behaviors. In another research, Özen (2009) determined that primary school eighth grade students' personal and social responsibility levels did not significantly differ based on their gender and income level.

In this research, individual social responsibility scores of teacher candidates significantly differed in favor of $4^{\text {th }}$ senior students. Başer (2015), on the other hand, reported that global social responsibility levels of social studies teacher candidates did not differ based on their school grades. The extra effort exerted by $4^{\text {th }}$ senior students to graduate from the school and to achieve Public Personnel Selection Examination (KPSS) may have resulted with higher individual social responsibility scores in favor of senior students. Also, their having received the teaching application and internship courses, which brought them a step closer to the profession of teaching, may be the underlying reason for their higher scores.

The individual social responsibility scores of teacher candidates were analysed on the basis of departments with t-test which showed a significant difference in favor of music teaching department. Accordingly, music teacher candidates' social responsibility levels can be assumed to be higher. Özalp, Tonus and Sarıkaya (2008) carried out a work on perception of social responsibility by economics department students and they found similar results with the present work. In a department based evaluation of the mentioned research's findings, economics department students were found to have higher social responsibility levels. Tunca (2012) investigated the professional value levels of primary school teachers and reported that, teachers' scores received from respecting differences and being against violence subscales did not differ based on their branches; while the scores were found to differ significantly in personal and social responsibility and being open to cooperation subscales and in overall scale. In this respect, personal and social responsibility scores show a significant difference, which is in favor of classroom and social studies teachers. However, in the descending order, the scores are ranked as those received by Classroom, Social Studies, Science and Technology, and Mathematics teachers, respectively. The lowest scores were received by Turkish teachers.

Music teaching department differs from the other departments of faculties of education by its own structure. Consequently, it includes an intensive curriculum which involves formation training courses, in addition to individual courses (piano, vocal, individual instruments) and collective courses (chorus, orchestra, etc.). In this curriculum, all courses systematically require extra training. For instance, a teacher candidate, who fails to prepare and implement his/her personal study program from individual instrument course, will not be deemed successful, since playing an instrument requires collective use of psycho-motor and affective skills. Music teacher candidates' comparatively higher individual social responsibility scores can be ascribed to the department's structure.

Positive "medium" level correlations were found between individual social responsibility and; discipline and responsibility $(\mathrm{r}=.58, \mathrm{p}<.01)$, honesty and sharing $(\mathrm{r}=.56, \mathrm{p}<.01)$ and sharing and affection. $(\mathrm{r}=.58, \mathrm{p}<.05)$. The relationship between individual social responsibility and GPA, $(\mathrm{x}=16, \mathrm{p}<.05)$ and respect and rightness $(\mathrm{r}=.15$, $\mathrm{p}<.05$ ) was found to be positive and weak. Also, personal values scale was found to have positive, strong, medium and weak relationships with its subscales.

Küçükşen and Budak (2017) found statistically significant and positive relationships between high school students' (N=410) Multi-dimensional Social Values Scale total scores and Global Responsibility Scale total scores $(\mathrm{r}=.45, \mathrm{p}=.001)$, and at all subscales of the both scales. Accordingly the findings of both works are seemingly consistent with each other.

As a result of the multiple regression analysis, performed to investigate the individual social responsibilities of the participating teacher candidates, $43 \%$ of the variance was found to be described by discipline and responsibility, 
confidence and forgiveness, sharing and respect, and honesty and sharing scores $\left(R^{2}=.43\right)$. The findings of ANOVA, conducted to determine the significance level of the regression analysis, shows that, the four independent variable has descriptive effect $\left(F_{6-232}=28.036, p=.000\right)$. As indicated by the standardized regression coefficients $(\beta)$, the significance levels of descriptive variables are ranked as; discipline and responsibility score $(\mathrm{r}=.31)$, sharing and respect score $(\mathrm{r}=.23)$, honesty and sharing score $(\mathrm{r}=.22)$ and confidence and forgiveness score $(\mathrm{r}=18)$ in descending order. Accordingly, discipline and responsibility, confidence and forgiveness, sharing and respect and honesty and sharing values describe $43 \%$ of the variance for individual social responsibility.

\section{Recommendations}

A very important course for providing the students with the sense of responsibility has been available in the curricula of faculties of education. The content of "Community service practices" courses provides a basis for teacher candidates to feel the satisfaction of helping others. Through these courses, teacher candidates can be provided with an in-depth insight into the importance of their activities for individuals and societies. In this context, the sense of "us" instead of "me" can be integrated into our existing values, thus enabling them to internalize this sense.

Turkish society has an innate sense of social responsibility with its already existing religious, cultural and social values. Societies attach great importance to the sense of benevolence. Additionally, the concept of collective and voluntary work has been a common practice in social life throughout the centuries. Teacher candidates, who have become isolated with the misuse of technology, can be provided with the satisfaction of producing and sharing something through performing intra-class and out-of-class activities. More activities involving collective work and sharing experiences can be included in the curricula.

During the courses, the importance of being sensitive against others' problems and raising unselfish individuals can be emphasized in addition to vocational training, thus encouraging teacher candidates to think and act accordingly.

Throughout their university lives, teacher candidates can be provided with environments in which they can feel the sense of "us" to a greater extent. These way teacher candidates can be able to internalize and implement the subject in non-formal environments as well.

Within the frame of social and cultural life of the related university, theater plays or meetings with benevolent visitors, who have attached great importance to social responsibility, can be organized to draw the attention of teacher candidates to this subject.

\section{References}

Akıncı-Vural, Z. B., \& Çoşkun, G. (2011). Kurumsal Sosyal Sorumluluk ve Etik., Gümüşhane Üniversitesi İletişim Fakültesi Elektronik Dergisi, 1, 61-87.

Aktan, C. C. (Ed.). (2007). Kurumsal Sosyal Sorumluluk Isşletmeler ve Sosyal Sorumluluk. İstanbul: İgiad Yayınları.

Aktepe, V., \& Yel, S. (2009, Yaz). İlköğretim Öğretmenlerinin Değer Yargılarının Betimlenmesi: Kırşehir İli Örneği. Türk Eğitim Bilimleri Dergisi, 7(3), 607-622.

Altunay, E., \& Yalçınkaya, M. (2011). Öğretmen Adaylarının Bilgi Toplumunda Değerlere İlişkin Görüşlerinin Bazı Değişkenler Açısından İncelenmesi. Kuram ve Uygulamada Eğitim Yönetimi, 17(1), 5-28.

Asan, T., Ekşi, F., Doğan, A., \& Ekşi, H. (2008). Bireysel Değerler Envanterinin Dilsel Eşdeğerlik Geçerlik ve Güvenirlik Çalışması. Marmara Üniversitesi Atatürk Ĕ̈itim Fakültesi Ĕgitim Bilimleri Dergisi, 27, 15-38.

Aydın, M. (2003). Gençliğin Değer Algısı: Konya Örneği. Değerler Eğitimi Dergisi, 1(3), 121-144.

Bacanlı, H. (2002). Değer Tercihleri: Psikolojik Kavram Analizleri. Ankara: Nobel Yayın Dağıtım.

Başer, E. H. (2015). Sosyal Bilgiler Öğretmen Adaylarının Küresel Sosyal Sorumluluk Düzeylerinin Çeşitli Değişkenler Açısından İncelenmesi. Yayınlanmamış Yüksek Lisans Tezi. Kütahya: Dumlupınar Üniversitesi Eğitim Bilimleri Enstitüsü.

Başol, O., Bilge, E., \& Kuzgun, Ş. (2012, Aralık). Öğrencilerin Kariyer Değerlerini Etkileyen Unsurların Tespitine Yönelik Bir Araştırma: Bireysel Değerler. Electronic Journal of Vocational Colleges, 57-68.

Büyüköztürk, Ş., Çakmak, E. K., Akgün, Ö. E., Karadeniz, Ş., \& Demirel, F. (2014). Bilimsel Araştırma Yöntemleri. Ankara: Pegem Akademi.

Cengil, M. (2015). Hitit Üniversitesi İlahiyat Fakültesi Öğrencilerinde Sorumluluk Duygusu ve Sorumluluk 
Davranışı Üzerine Bir Araştırma. Harran Üniversitesi İlahiyat Fakültesi Dergisi, 20(33), 7-23.

Demirutku, K., \& Sümer, N. (2010). Temel Değerlerin Ölçümü: Portre Değerler Anketinin Türkçe Uyarlaması. Türk Psikoloji Yazıları, 13(25), 17-25.

Dilmaç, B., \& Bircan, H. H. (Ed.). (2015). Değerler ve Değerler Psikolojisi. Ankara: Pegem Akademi.

Eraslan, L. (2011). Bireysel Sosyal Sorumluluk Ölçeği'nin (BSS) Geliştirilmesi: Geçerlik ve Güvenirlik Çalışması. Aile ve Eğitim Kültür ve Toplum Dergisi (pp. 81-91).

Ercan, B. (2009). Ortä̈ğretim Öğretmenlerinin Sosyal Sorumluluk Anlayıs ve Uygulamaları: Antalya Örneği. Yayınlanlanmamış Yüksek Lisans Tezi. Antalya: Akdeniz Üniversitesi Sosyal Bilimler Enstitüsü.

Erdoğan, E. (2016). Hemşirelerin Bireysel Sosyal Sorumluluk Düzeyleri ile Yaşam Doyumunun Demografik Değişkenlere Göre Araştırılması. Yayınlanmamış Yüksek Lisans Tezi. Isparta: Süleyman Demirel Üniversitesi Sosyal Bilimler Enstitüsü.

Gömleksiz, M. N., \& Cüro, E. (2011). Sosyal Bilgiler Dersi Öğretim Programında Yer Alan Değerlere İlişkin Öğrenci Tutumlarının Değerlendirilmesi. Uluslararası İnsan Bilimleri Dergisi, 8(1), 95-134.

Güngör, E. (1993). Değerler Psikolojisi. Amsterdam: Hollanda Türk Akademisyenler Vakfi.

Gürkan, H., Çamlıyer, H., \& Saracaloğlu, A. S. (2000). Beden Eğitimi Öğretmeni Adaylarının Değerler Sistemi. Gazi Beden Eğitimi ve Spor Bilimleri Dergisi (Gazi BESBD), V(1), 35-52.

Halstead, J. M., \& Taylor, M. J. (2000) Learning and Teaching About Values: A Review of Recent Research. Cambridge Journal of Education, 30(2), 169-202. https://doi.org/10.1080/713657146

Hatch, C. D., \& Stephan, S. A. (2015). Gender Efffects On Perceptions of Individual and Corporate Social Responsibility. Business and Economics; Thunder Bay, 17(3), 63-71.

Karadağ, C. A. (2017). Kurumsal Sosyal Sorumluluk Faaliyetlerine İlişkin Öğretmen Görüşlerinin İncelenmesi. Gaziantep: Gaziantep Üniversitesi Eğitim Bilimleri Enstitüsü.

Karasar, N. (2004). Bilimsel Araştırma Yöntemi. Ankara: Nobel Yayın Dağıtım.

Kocabaş, İ. (2014). Üniversite Öğrencilerinin Gözünde Sosyal Sorumluluk Imajı: Selçuk Üniversitesi Örneği. Yayımlanmamış Yüksek Lisans Tezi. Konya: Selçuk Üniversitesi Sosyal Bilimler Enstitüsü.

Küçükşen, K., \& Budak, H. (2017). Lise Öğrencilerinin Sosyal Değer Tercihlerinin Küresel Sosyal Sorumluluk Düzeylerine Etkisi. İnsan ve Toplum Bilimleri Araştırmaları Dergisi, 6(3), 1813-1826.

Limthanakom, N., Lauffer, W., Mujtaba, B. G., \& Murphy Jr., E. F. (2008). The Ranking of Terminal and Instrumental Values by Working Professionals in Thailand, Singapore and The United States: What Is Important and How Do They Impact Decision-Making? International Business \& Economics Research Journal, 7(4), 45-60.

Myyry, L. \& Helkama, K. (2001). University Students' Value Priorities and Emotional Empathy. Educational Psychology, 21(1), 25-40. https://doi.org/10.1080/01443410123128

Nelson, D. B., \& Low, G. R. (2004). Personal Responsibility Map (PRM), Oakwood Solutions, LLC.

Oğuz, E. (2012). Öğretmen Adaylarının Değerler ve Değerler Eğitimine İlişkin Görüşleri. Kuram ve Uygulamada Eğitim Bilimleri, 12(2), 1309-1325.

Özalp, İ., Tonus, H. Z., \& Sarıkaya, M. (2008). İktisadi ve İdari Bilimler Fakültesi Öğrencilerinin Kurumsal Sosyal Sorumluluk Algılamaları Uzerine Bir Araştırma. Anadolu Üniversitesi Sosyal Bilimler Dergisi, 8(1), 69-84.

Özdemir, S., \& Sezgin, F. (2011). Öğretmen Adaylarının Bireysel ve Örgütsel Değerler ile Öğrencilerde Görmek İstedikleri Değerlere İlişkin Önem Sırası Algıları. Uşak Üniversitesi Sosyal Bilimler Dergisi, 4(2), 1-21.

Özen, Y. (2009). İlköğretim 8. Sınıf Öğrencilerinin Kişisel ve Sosyal Sorumluluk Yordayıcılarının İncelenmesi. Yayınlanmamış Doktora Tezi. Erzurum: Sosyal Bilimler Enstitüsü.

Pehlivan, İ. (2003). Yönetsel, Mesleki ve Örgütsel Etik. Ankara: PegemA Yayınc1lık.

Rokeach, M. (1973). The Nature of Human Values. New York, NY: Free Press.

Roy, A. (2003). Factor Analysis and Initial Validation of The Personal Values Inventory (Unpublished doctoral dissertation). Tennessee State University, USA.

Saracaloğlu, A. S., Evin-Gencel, İ., \& Altın, M. (2016). Öğretmen Adaylarının Sahip Olduğu Sosyal Değerler İle 
Eleştirel Düşünme Düzeylerinin İncelenmesi. Ankara: Atatürk Kültür, Dil ve Tarih Yüksek Kurumu, Atatürk Araştırma Merkezi. Cilt I, 441-465.

Saracaloğlu, A. S., Sayg1-Gerçeker, C., \& Aladağ, S. (2018). The Relationship Between The Values of Primary School and Music Teacher Candidates and Their Cheating Attitudes. Journal of Education and Learning, 7(1), 281-298. http://doi.org/10.5539/jel.v7n1p281

Saracaloğlu, A. S., Uça, S., Baydilek, N. B., \& Coşkun, N. (2013). Öğretmen Adaylarının Demokratik Tutumları ile Değer Algılarının İncelenmesi. Adnan Menderes Üniversitesi Eğitim Fakültesi Eğitim Bilimleri Dergisi, $4(1), 45-59$.

Schwartz, S. H., \& Bardi, A. (2001). Value Hierarchies across Cultures: Taking a Similarities Perspective. The Journal of Cross Cultural Psychology, 32(3), 268-290. http://doi.org/10.1177/0022022101032003002

Secchi, D. (2009). The Cognitive Side of Social Responsibility. Journal of Business Ethics, 88(3), 565-581. https://doi.org/10.1007/s10551-009-0124-y

Sezer, A., Çoban, O., \& Akşit, İ. (2017). Öğretmenlerin Sorumluluk Değeri Algılarının İncelenmesi. Uşak Üniversitesi Eğitim Araştırmaları Dergisi, 3(1), 122-144. https://doi.org/10.29065/usakead.285941

Taşdan, M. (2010). Türkiye'deki Resmi ve Özel İlköğretim Okulu Öğretmenlerinin Bireysel Değerleri ile Okulun Örgütsel Değerleri Arasındaki Uyum Düzeyi. Kuram ve Uygulamada Eğitim Yönetimi, 16(1), 113-148.

Töremen, F. (2011). Öğretmen Adaylarının Sorumluluk Eğitimi. Kuram ve Uygulamada Eğitim Bilimleri, 11(1), 263-277.

Tunca, N. (2012). İlköğretim Öğretmenleri İçin Mesleki Değerler Ölçeğinin Geliştirilmesi ve İlköğretim Öğretmenlerinin Mesleki Değerlerinin Belirlenmesi (Yayınlanmamış doktora tezi, Anadolu Üniversitesi Eğitim Bilimleri Enstitüsü).

Ulusoy, K., \& Dilmaç, B. (2015). Değerler Ĕgitimi. Ankara: Pegem Akademi.

Unutkan, Ö. P. (2005). Okul Öncesi Dönemde Sorumluluk Eğitimi. In A. Oktay, \& Ö. P. Unutkan (Eds.), Okul öncesi eğitimde güncel konular (pp. 189-196). İstanbul: Morpa.

Yıldırım, Ş. (2016). Ortaöğretim Öğrencilerinde Kişisel Sorumluluk ve Ruh Sağllğ̆ Düzeyleri Arasındaki İlişki: Adana Çukurova ilçesi örneği. Yayınlanmamış Yüksek Lisans Tezi. Adana: Çağ Üniversitesi Sosyal Bilimler E nstitüsü.

Yılmaz, K. (2011). Eğitim Fakültelerinin Sosyal Sorumluluğu ve Topluma Hizmet Uygulamaları Dersi: Nitel Bir Araştırma. Kuramsal Eğitimbilim, 4(2), 86-108.

Yurtal, F., \& Yontar, A. (2006). Sınıf Öğretmenlerinin Öğrencilerinden Bekledikleri Sorumluluklar ve Sorumluluk Kazandırmada Kullandıkları Yöntemler, Ç.Ü. Sosyal Bilimler Enstitüsü Dergisi, 15(2), 411-424.

\section{Note}

Note 1. This study is the full paper version of the oral presentation, presented in 25th congress on educational sciences (UEBK 2016) organized between 21-24 April 2016.

\section{Copyrights}

Copyright for this article is retained by the author(s), with first publication rights granted to the journal.

This is an open-access article distributed under the terms and conditions of the Creative Commons Attribution license (http://creativecommons.org/licenses/by/4.0/). 